Available online at: http://proceeding.rsfpress.com/index.php/ic-smart/index

Proceeding on International Conference of Science Management Art Research Technology

(IC-SMART)

Volume 1 Number 1 (2020): 118-136

\title{
Interdependence of Loan and Deposit Volumes at Government-Owned, Private, and Joint-Venture Banks in Indonesia During 2003-2017
}

\author{
Masfar Gazali ${ }^{1}$, Matrodji Mustafa ${ }^{2}$ \\ ${ }^{1}$ Trisakti University, Indonesia; \\ ${ }^{2}$ Mercu Buana University, Indonesia \\ ${ }^{1}$ E-mail address masfar.gazali@trisakti.ac.id; ${ }^{2}$ E-mail address \\ matrodji.mustafa@mercubuana.ac.id
}

\begin{abstract}
This study examines the interdependence of loans and deposits at government-owned banks, private banks, and joint-venture banks in Indonesia. This study uses monthly time series of loans and deposits from January 2003 to December 2017. The Combined Loans and Combined Deposits from each group of banks are used for this empirical study. Based on Augmented Dickey-Fuller tests, this study finds that all the series are stationary after first-differencing. This study also finds that loan and deposit volumes are cointegrated at government owned banks and private banks but not at joint-venture banks. Analyzing the interdependence of loans and deposits, this study uses the vector error correction model (VECM) for government-owned as well as private banks and the vector autoregressive (VAR) model for joint-venture banks. Based on Granger Causality tests, the results show that the interdependence of loans and deposits exists only in government-owned banks. In private banks, the causality was in one direction in which loan volumes depend on deposit volumes. No causality of loans and deposits was found in joint venture banks. The intense competition in the banking industry affects the strategy adopted include aggressive marketing executed by the bank's relationship managers. They initiate loans, and funding will follow. Hence, in modern banking, deposits affect loans, and loans affect deposits only observed at governmentowned banks. Private banks follow the traditional intermediary theory, while joint-venture banks follow no theory.
\end{abstract}

Keywords: Interdependence, Loans, Deposits, VAR, VECM, Granger

This is an open access article under the CC-BY-NC license

\section{INTRODUCTION}

A minimal definition of banks is that banks are institutions that accept money deposits and extend loans (Mettenheim, 2013). A bank can be defined in terms of the economic functions it performs, the services it offers, and the legal basis for its existence (Rose and Hudgins, 2013, 2). In the economic function, it performs bank channels funds from savers to users. In this function, a bank acts as an intermediator between depositors and borrowers. By transferring savings into an investment, banks 
Proceeding on International Conference of Science Management Art Research Technology (IC-SMART),

Vol. 1 (1), 118-136

Interdependence of Loan and Deposit Volumes at Government-Owned, Private, and Joint-Venture Banks in Indonesia During 2003-2017

Masfar Gazali, Matrodji Mustafa

help the economy to grow. In addition to channeling funds, a bank provides a payment system for the transaction of goods and services. In the services a bank offers include but are not limited to checking accounts, saving accounts, loans for businesses, consumers, and government. Bank services are expanding over time. Koch and MacDonald $(2015,21)$ called banks that offer a broad range of financial products and services as universal banking and sometimes called a one-stop financial supermarket. When the government decides to regulate or supervise banks, it has to define what is and what is not a bank. This legal definition is very important for the purpose of enforcing its rules. In Indonesia, based on the Banking Act 1998, a bank is defined as an entity that collects funds in the form of deposits and extending them to the borrowers in the form of a loan or other placement for the purpose of improving the welfare of people.

Levine (2005) argued that the banking sector could facilitate economic growth through its five functions. The functions include providing information about possible investments and allocate capital, monitoring investments after providing credit, facilitating trading, risk diversification, and risk management; mobilising deposits, and facilitating the exchange of goods and services.

Banking sector development can be defined as the increase in the ability of the banking sector to facilitate economic growth (Aluko and Ajayi, 2018). The measures of banking sector development indicators include access, efficiency, and stability of financial systems across and within countries (FSDI@worldbank.org). The efficiency dimensions include profitability, efficiency, and competitiveness. Gelbard and Leite (1999) suggested six indicators of financial development. These indicators include competitiveness of the banking systems, availability of financial products, financial liberalization, institutional environment, integration with international financial markets, and the degree of sophistication of monetary policy instruments.

This study relates to the efficiency of the banking industry. Competition is needed in the banking sector since the competition is expected to remove cost inefficiencies. Efficiencies in the banking sector can reduce overhead costs so that the lending rate will be lower. The efficient banking sector can create welfare gains and help in the growth of the economy (Jayaratne and Strahan, 1996). Banking regulators are interested in banking competition and alter less competitive to more competitive levels for better economic growth (Kapsis, 2012). For a bank, competition causes every bank to take various measures to maintain or to improve its earnings, including making any efforts to maintain a good relationship with its existing customers.

The relation of the competition in the banking industry with this study follows the customer relationship doctrine (Rose and Hudgins, 2013). Competitions among banks in loan markets cause banks to do their best to maintain their loan customers as well as to look for the new ones. In this doctrine, customer demand for loans must be first satisfied, and banks seeking funding sources such as purchased deposits will follow. In this case, loan demand precedes bank funding. In other words, the volume of credits influences the volume of deposits as the effect of competition. This is in addition to banks' traditional function as an intermediator in which the deposit volumes affect the loan volumes. The intense competition among banks does not remove the banks' traditional function as an intermediator. This can be a basis for a statement that in a developed banking system, the deposit volumes affect the loan volumes and the loan volumes affect deposit volumes.

Based on the above discussion, the current study on the interdependence of loan and deposit volumes at Indonesia banks can be used to explain whether the banking system in Indonesia is still underdeveloped in terms of the existence of competition. This follows Nguyen et al. ( 2018) that suggests that in an underdeveloped banking system, bank deposits have a positive and significant impact on bank loans, but the reverse relationship is not significant. Hence, in a developed banking system, bank deposits and bank loans affect each other. 
Proceeding on International Conference of Science Management Art Research Technology (IC-SMART),

Vol. 1 (1), 118-136

Interdependence of Loan and Deposit Volumes at Government-Owned, Private, and Joint-Venture Banks in Indonesia During 2003-2017

Masfar Gazali, Matrodji Mustafa

According to Abel et al. (2017). intense competition among banks in the deposit market causes banks to promise depositors to get bank loans with better conditions such as a greater amount and longer tenor. This means that since customer wants to obtain loans, then they place their money first in bank deposits. Thus deposits will cause loans.

The interdependence of loan and deposit volumes implies that the activities of collecting deposits and granting loans are carried out by a single institution, not by two-separately institutions. The next section on the discussion of the economies of scope provides the explanation that the two activities of collecting deposits and granting loans are better carried-out by one financial institution.

Currently, a broad range of financial services is offered by banks in addition to taking deposits and extending loans. This phenomenon can be explained by the economies of scope concept. Textbooks in economics, for example, Keat dan Young $(2009,276)$, defined the economies of scope as the lower cost per unit if two or more products or services are produced by one firm compares with that if they are produced by two or more separate firms. For banks, the economies of scope mean that the function of collecting deposits and the function of extending loans will be more efficient if they are performed by one financial institution than if the are performed by two separate financial institutions. According to Rose dan Hudgins $(2013,87)$, the economies of scope implied that banks would have cost-saving if they offer various services to customers since they can share the same office, management time, and bank equipment.

In the case of two financial services provided by banks, deposit accounts and bank loans, there will create a synergy since these two activities will utilize the same overhead in the bank (Kashyap et al., 2002). The same overhead includes personnel expenses and facilities such as computers and branch networks owned by the bank. According to Kashyap et al. (2002, the overhead is not limited in the form of operational expenses but also in the form of obligation to maintain liquidity. The activity of deposit-taking and the activity related to loan commitment requires the bank to maintain a liquidity position. The number of liquid assets will be lower when deposit-taking and loan commitment is performed by one institution compare with two or more separate institutions.

In searching for loan customers, a bank must compete with non-bank financial institutions, in addition to compete with other banks. This competition will force banks to make any effort to maintain their customers, in addition to look for new ones. The bank must provide the best services to customers, including makes any efforts to meet customer needs such as credit. Customer demand for loans must be first satisfied, and banks seeking funding sources such as purchased deposits will follow. In this case, loan demand precedes bank funding. In other words, the volume of credits influences the volume of deposits.

Meanwhile, taking deposits incur interest burden for the bank. The money from depositors should be placed in earnings assets, mainly credits. The amount of credit is the same as the amount of cash received from depositors after the obligation for reserve requirement is met. In this situation, the more the volume of deposit taken, the more the volume of credit. In this situation, the volume of loans or credit depends on the volume of deposits. In addition to credits, banks also have investment alternatives, which cause not all of the funds placed in credits. If this is the case, then an increase in deposits does not cause credit to increase. There is also another option for the bank to use borrowed funds instead of deposits as a source for credits. Hence, the credit volume does not affect the volume of deposits.

Since there is a gap between the time of deposits received and the time of loans extended to the customer, this situation leads to the justification that an increase in the volume of deposits causes a future increase in the volume of credit. In other words, current credits are affected by previous deposits. 
Sometimes banks use bridging financing for credits using other sources of funds such as borrowed funds before obtaining purchased deposits. In this situation, current deposits depend on previous credits. Since ending loan balances in a particular month are carried forward to the next months, this implies that loan balance in the current month is affected by loan balances from previous months. This case is also true for deposits. The current balance of the deposit is affected by previous deposit balances.

Summaryzing the discussions, it is reasonable to state that there is a strong interrelationship or interdependence of credit and deposits. In this study, the term deposits include demand deposits, saving deposits, time deposits, and certificates of deposits.

The ownership of commercial banks in Indonesia is grouped into National-Government-owned Banks, Privately-owned Banks, Provincial-government-owned banks, Foreign Banks, and Jointventure Banks. The joint-venture banks are owned by national and foreign banks. This study will analyze the interdependence of loan and deposit at national government-owned banks, at private banks, and a joint venture banks as a group. The Loan and deposit volumes are the sums of those of individual banks in the group.

\section{I.1.Problem identification}

Information on loan and deposit volumes is important since they are used for signaling the economic condition of a country. In Indonesia, the behavior of loan and deposit volumes during the period of January 2003-December 2017 is depicted in Figure1. Based on monthly data, loan volumes from 2003 to 2017 show a consistent increase over time for all groups of banks, as depicted in figures 1.
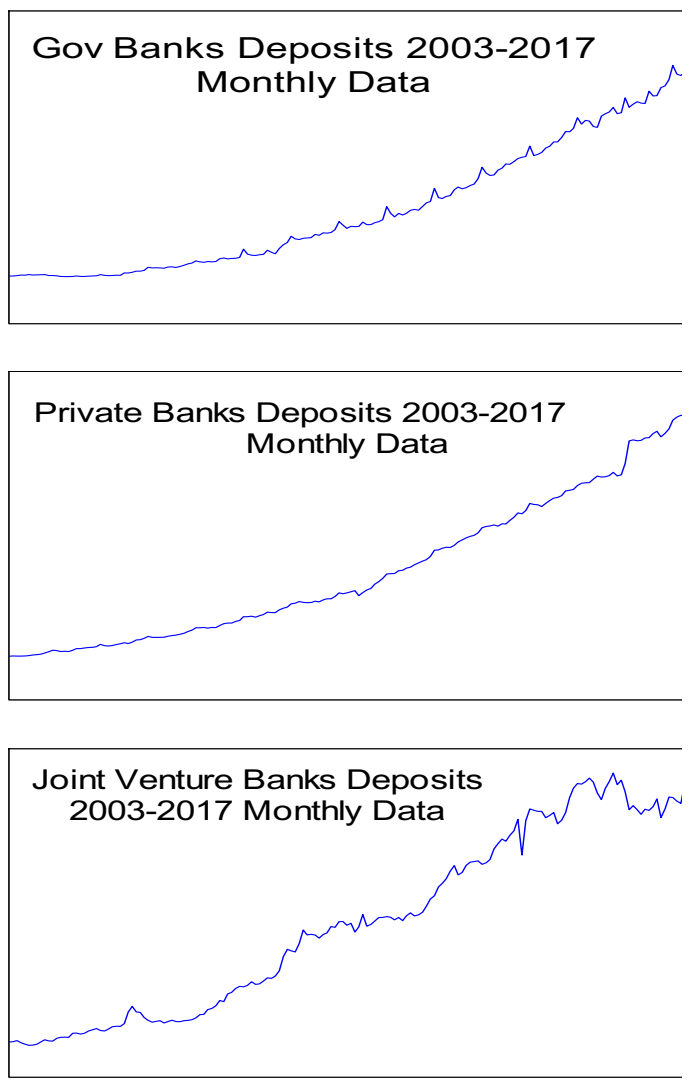
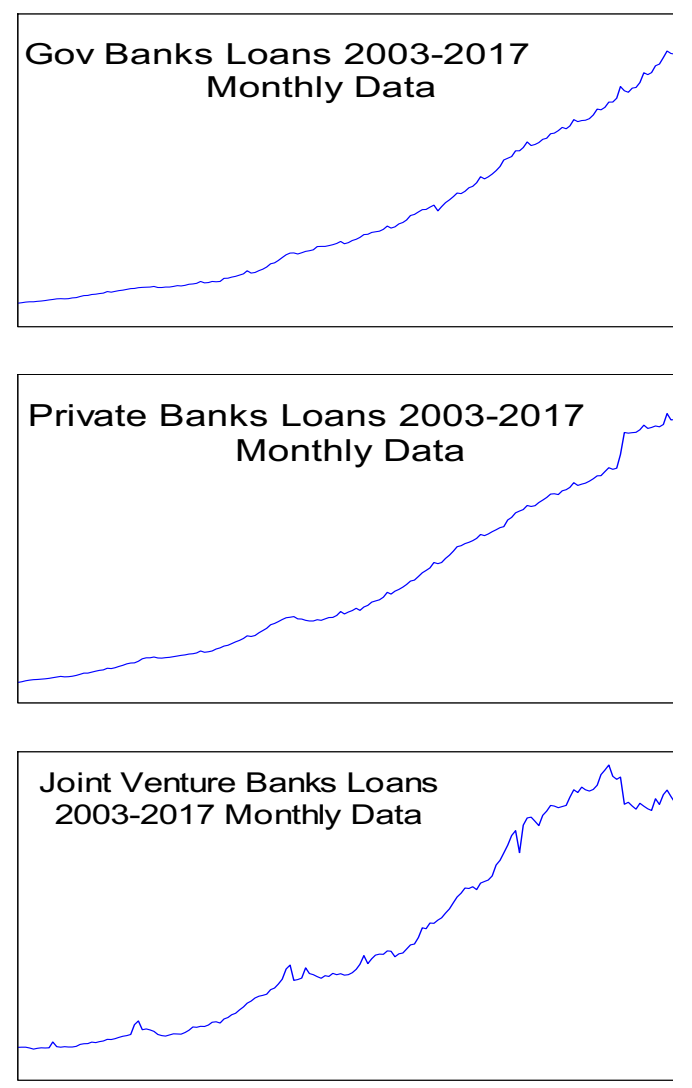
Proceeding on International Conference of Science Management Art Research Technology (IC-SMART), Vol. 1 (1), 118-136

Interdependence of Loan and Deposit Volumes at Government-Owned, Private, and Joint-Venture Banks in Indonesia During 2003-2017

Masfar Gazali, Matrodji Mustafa

Figure 1 The Graphs of Monthly Deposits and Loans Balances at Government, Private, and Joint Venture Banks' Groups 2003-2017

For the same period, deposit volumes collected also show an increasing trend over time. The graph shows the phenomena of a comovement of loan and deposit volumes depicted in the figure. This raises the question of whether deposit volume affects loan volumes, loan volume affects deposit volumes, or loan volumes and deposit volume affect each other. The other question that can be raised is whether the movement in loan cointegrated with the movement in a deposit. Still, another question is whether the comovements of loan and deposit volume last for a long period.

Figure 2 below shows that in Government-owned banks, the distance between volumes of loan and deposit relatively constant over time, or the distance may follow certain functions. The distance is measured by a gap in loan volume and deposit volume. This fact of constant distance becomes a reason to state that cointegration exists between loan and deposit volumes at government-owned banks.

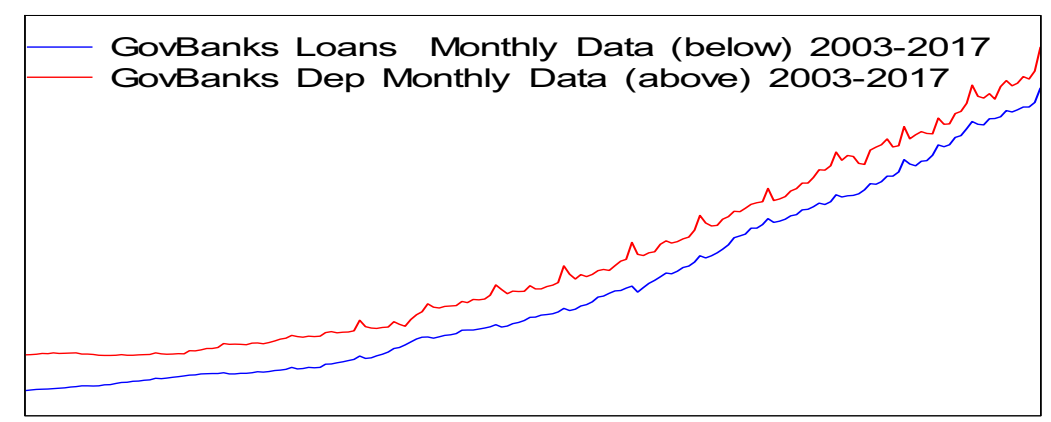

Figure 2 The Comovements of Deposits and Loans at Government-owned Banks for Period 2003-2017

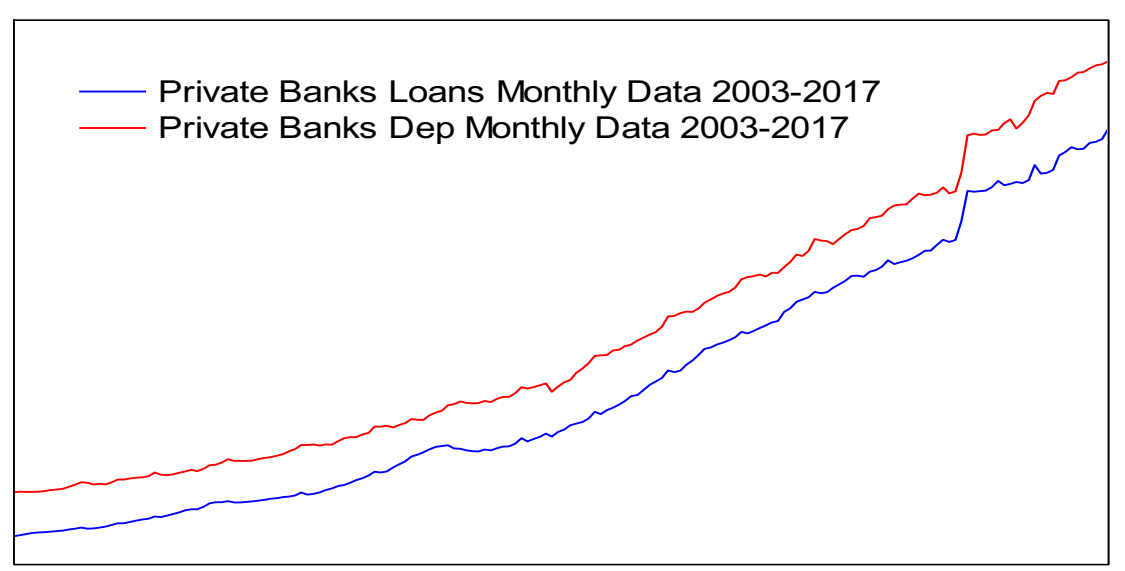

Figure 3 The Comovements Deposits and Loans at Private Banks for Period 2003-2017

The trend of loan and deposit volumes for private banks is depicted in Figure 3. Figure 3 shows that the volume of loans and deposits maintain the same gap overtime during the period from 2003 to 2017. This behavior indicates the existence of co-movements of loans and deposits at Private Banks 
observed. The co-movement of loan and deposit volumes that is in an indication that loans and deposits are cointegrated.

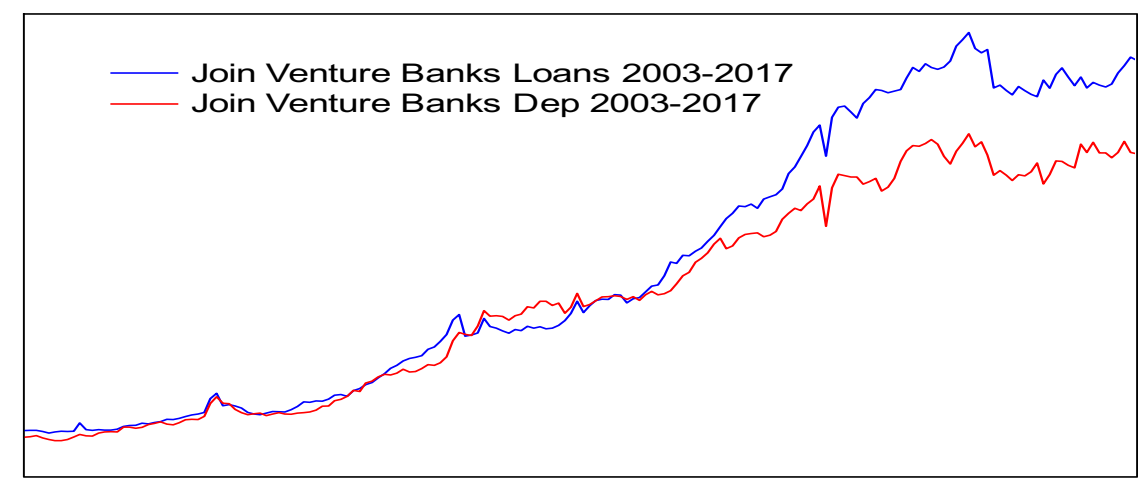

Figure 4 The Movements of Deposits and Loans at Joint Venture Banks for Period 2003-2017

Figure 4 shows that the behavior of loan and deposit volumes at joint venture banks is similar to that of government and private banks, in that loan and deposit volumes increase over time. The difference is that the loan and deposit volumes at joint venture banks do not maintain the same distance. This fact becomes a reason to state that no-cointegration exists between loan and deposit volumes at jointventure banks. At government banks and private banks, the deposit volumes are always higher than loan volumes. At joint-venture banks, this behavior does not exist.

Many studies only examine the effect of loans on deposit or the effect of deposit on loan in one direction. So far, only one study was conducted on loan and deposit interdependence by Nguyen et al. (2018) using a sample of banks in Vietnam. This current study differs from previous studies in that this study investigates the two-way interdependence of loans and deposits. This study also specifically investigate the interdependence of loan and deposit in three different groups of banks in Indonesia.

\section{I.2.Problem Formulation}

The focus of this study is to answer the following questions for each group of banks: Is the volume of loans and deposits cointegrated. Does the volume of loan affect the volume of deposits in one direction; Does the volume of deposits affect the volume of a loan in one direction; Do the volume of deposits and the volume of loan affect each other in two directions.

\section{I.3.The purpose of this study}

This study seeks to investigate whether the interdependence of loan and deposit exists in governmentowned banks, private banks, and joint venture banks. Specifically, the purpose is to examine the direction of the relationship, unidirectional or bidirectional. From the findings, it can be concluded whether Indonesian bankings are developed or underdeveloped. According to Nguyen et al. (2018), in an underdeveloped banking system, bank deposits have a positive and significant impact on bank loans, but the reverse relationship is not significant.

\section{LITERATURE REVIEW}

\section{II.1.The Co-existence of Lending and Deposit-Taking}


Proceeding on International Conference of Science Management Art Research Technology (IC-SMART),

Vol. 1 (1), 118-136

Interdependence of Loan and Deposit Volumes at Government-Owned, Private, and Joint-Venture Banks in Indonesia During 2003-2017

Masfar Gazali, Matrodji Mustafa

Kashyap et al. (2002) argued that there would be synergies between the activities of taking deposits and activities of lending since both require banks to hold large balances of liquid assets. These two activities can share the costs of the liquid-asset stockpile if deposit withdrawals and loan commitment takedowns are imperfectly correlated. Lewis (1992) analyzed the synergies between the activities of taking deposits and activities of lending from banks as information processors and liquidity insurers. He argued that banks could get information advantages since banks are acting as their customers' bookkeepers. By monitoring their customers' transactions, banks would be able to get information about their suitability for credit and ability to repay loans. This is private information that gives banks an advantage position to become efficient lenders

\section{II.2.The Concept of Economies of Scope}

This concept argues that two or more goods will be more efficiently produced by one firm than they are produced through two or more different firms for each product. Banks produce many financial services to customers. Relating to this study, deposit-taking and extending loan activities will be more efficient if both activities are provided by one institution than that by two separate institutions. Rose and Hudgins ( 476) defines economies of scope as a situation in which the joint cost of producing two or more services in one firm are less than the combined costof producing each of these services through separate firms. The cost savings from one bank producing many services may be smaller because some inputs such as management, computer, dan office facilities are shared. Saunders and Cornett $(2004,329)$ defines economies of scope as the ability of financial institutions to generate synergistic cost savings through joint use of inputs in producing multiple products.

In the context of this study, products offered by banks in the form of various deposits and various loans will be more efficiently produced by one institution (bank) than if deposits and loans are provided by two separate institutions. Lewis $(1992,211)$ explains economies of scope for providing two products, deposits and loans, in one institution based on information advantages.. In this regard, bank acts as a bookkeeper for depositors By monitoring profile of transaction acount made by depositors bank will be able to evaluate the suitability for credit and the ability to repay if the customer obtain the loan. This private information gives banks an advantage over non bank credit institution that provide credit only and makes banks to be efficient lenders. Once credit is granted, the customer account becomes a continuing source of information. This will allow banks to monitor and identify problem loans. It is from deposit accounts banks will be able to make loans with the same expected return but with lower default risk. With this informational economies of scope, two activities, taking deposits and making loans, will be more efficient if conducted by only one institution.

The expalanation for economies of scope is also provided by Kashyap et al (2002). Kashyap et al (2002) argue that there is a significant synergy between deposit-taking and lending activities. In lending activities, once a bank has decided to make a loan commitment, a borrower has the option to take the loan down on demand over some specified period of time. The loan customer can withdraw funds any time, and these withdrawals will random from the bank's perspective. Both on demand deposits and on loan commitments, a bank has to maintain liquid assets to accommodate unpredictable withdrawals. The authors called the liquid asset maintained as costly overhead that is needed by bank to carry out its job effectively. This overhead consists of cash and marketable securities that a bank holds as buffer stock on asset side. This overhead is burdersome since on the cash component, there is forgone interest. Also, securities that bear a interest rate impose a cost on bank shareholders because of double taxation of the interest income. Finally, a large balance of liquid assets gives managers a discretion, and is to increase agency costs. 
Proceeding on International Conference of Science Management Art Research Technology (IC-SMART),

Vol. 1 (1), 118-136

Interdependence of Loan and Deposit Volumes at Government-Owned, Private, and Joint-Venture Banks in

Indonesia During 2003-2017

Masfar Gazali, Matrodji Mustafa

Since both deposits and loan commitments require liquid-asset holdings, and this overhead is costly, the potential for synergy between the two activities becomes clear. There will be a synergy to the extent that the two activities can "share" some of the costly overhead, so that a bank that offers both deposits and loan commitments can get by with a smaller total volume of liquid assets on its balance sheet than would two separate institutions that each specializes in only one of the functions. The synergy exists as long as deposit withdrawals and commitment takedowns are not too highly correlated. Intuitively, a deposit taking bank holds a buffer stock of cash and securities as a hedge against a state of the world where there are large deposit outf lows. But in many other situations, there are no deposit outf lows, and the buffer stock just sits idle. If the buffer stock can instead be used to accommodate commitment takedowns in these situations, efficiency will be enhanced.

There will be synergies between the two activities to the extent that both require banks to hold large balances of liquid assets: Kashyap et al (2002) summarize that If deposit withdrawals and commitment takedowns are imperfectly correlated, the two activities can share the costs of the liquidasset stockpile

\section{II.3.Theoretical Concept In Which Deposits affect Loans Financial Intermediation Theory of banking}

The function of banks as intermediaries are necessary to overcome information barriers facing depositors in finding borrowers or borrowers findings depositors directly. This situation reinforces the importance of banks as institutions for intermediation (Mettenheim, 2013). The financial Intermediation Theory of banking holds that banks borrow from depositors and lend to borrowers. In this theory banks do not differ from other non bank financial institutions (Werner 2016, 362). If banks gather more deposits they will lend more so that volume of loan will depend on volume of deposits. This theory considers banks as financial intermediaries either individually or collectively. As a financial intermediary, a bank cannot reject incoming customers to deposit money in their accounts such as demand deposits, saving deposits, or time deposits. Since this deposit is interest bearing, a bank must be able to pay interest on deposits from interest revenues. In this case a bank extend the money by placing into earnings assets such as loans. The loan volumes will depend on deposit volumes.

\section{II.4.Theoretical Concept In Which Loans affect Deposits}

\section{II.4.1.The Customer Relationship Doctrin}

The customer relation is the bank's main asset (Ahtiala, 2005). Competitions among banks causes banks to make any efforts to maintain their customers as well as to find the new ones. For a bank manager, turning down a request for profitable loan with the usual excuse bank have no funds is not well received by bank customers. If the loan request is denied, bank will loss customers and any future business from the disappointed customers. The customer relationhsip doctrin proclaims that the top priority of bank is to make loans to customers whom the bank expects to get profit (Rose and Hudgins, 2013). In this case all loans whose returns exceed cost and whose quality meets the bank's credit standard should be made. In a modern financial intermediation theory, it would be reasonable for banks that discover a qualified individual projects and sell them to primary investor or depositors.

Banks usually want to maintain its relation with its mutually beneficial customers and will be ready to meet their financing and non credit needs. It is difficult for banks to refuse if prime customers ask for credit. Banks will make any efforts to get the funds available. This is the case that the volume of deposits depends on the volume of loan. 


\section{II.4.2.The Credit Creation Theory of Banking}

The deposit volumes will increase in two ways: First, when the customer deposits his money with banks, and when a bank advances loans to loan customers, bank does not pay in cash, bank opens current accounts. The later, the bank creates credits or deposits.

The credit creation takes place when a bank make a loan to its customer. Here, the bank records the loan under bank assets. At the same time, bank credited the deposit account of the loan customer as liability.

\section{II.4.3.The Fractional Reserve Theory of Banking}

This theory of banking argues that each bank is a financial intermediary. However, the banking system as a whole creates money, through the process of 'multiple deposit expansion (Werner 2016). This theory differs from the intermediation theory in that The Fractional Reserve Theory of Banking argues that, banks collectively or the banking system as a whole, creates money, through the process of multiple deposit expansion. A bank individually cannot create money or deposits. From initial deposit, a bank will put part of it into central bank to meet minimum reserve requirement and the remainder will be lent to loan customers. In this case, deposits affect loans. In the process the lending banks give cheques to their loan customers and in turn, the customers deliver the cheques to other parties. If the other parties can deposit the cheques at other banks. In the process loans create deposits or loans affect deposits.

\section{II.4.4.Theoretical Concept In Which Loans and Deposits affect each other}

In the customer relationhsip doctrine previously discussed, a customer demand for loans must be first satisfied and bank seeking funding sources such as purchased deposits will follow. In this case, loan demand precedes bank funding. In other words, the volume of credits influences the volume of deposits as the effect of competition

\section{II.4.5.Vector Autoregression (VAR) and Vector Error Corection (VEC) Models}

A VAR model is used when two time series depends on one to another. VAR model is in a family of autoregressive model. In VAR or autoregressive model, the last figure in a time series is influenced by its previous figures. Including these previous figures as independent variables because of the fact that the only available data is the time series itself. An Autoregressive model can be used to avoid subjectivity issue when exogeneous variables should be included. Different persons will include different variables into the model. If deposits and loans affect each other, then VAR model can be used. Bivariate VAR is a vector of a pair autoregression that consists of loan series and deposit series. Since the two series is believed to depend each other, then the current value of loan depends not only on its lagged values but also on the lag values of deposits. The current value of deposit depends not only on its lagged values but also on the lag values of loans.

The Vector Autoregression (VAR) model employed in this study is as follow:

$$
\begin{aligned}
& \text { Loan }_{t}=\alpha+\sum_{i=1}^{k} \beta_{i} \text { Loan }_{t-i}+\sum_{i=1}^{k} \varphi_{i} \text { Deposit }_{t-i}+\varepsilon_{1 t} \\
& \text { Deposit }_{t}=\delta+\sum_{i=1}^{k} \lambda_{i} \text { Loan }_{t-i}+\sum_{i=1}^{k} \theta_{i} \text { Deposit }_{t-i}+\varepsilon_{2 t}
\end{aligned}
$$


The number of lags can be based on AIC or SIC statistics or log-likelihood ratio.

\section{II.4.6.Unit Root Test or Stationary Test}

To know whether time series data is stationary or not is to use statistical test called unit root test. This study will use Augmented Dickey Fuller (ADF test) for stationary. The ADF test has the following equations:

Model without intercept and trend: $\Delta Y_{t}=\delta Y_{t-1}+\sum_{t=1}^{n-1} \beta \Delta Y_{t-1+1}+\varepsilon_{t}$

Model with intercept and no trend $\Delta Y_{t}=\alpha_{0}+\delta Y_{t-1}+\sum_{t=1}^{n-1} \beta \Delta Y_{t-1+1}+\varepsilon_{t}$

Model with intercept and trend $\Delta Y_{t}=\alpha_{0}+\alpha_{1} T+\delta Y_{t-1}+\sum_{t=1}^{n-1} \beta \Delta Y_{t-1+1}+\varepsilon_{t}$

Testing unit root test with ADF test has a the following null and alternative hipotheses (Tsay, 2010). $H_{0}: \delta=0$, means the seris has a root or not stationary with an alternative hipothesis of $H_{a}: \delta<0$ that is the series has no unit root or has been stationary

Ho is rejected if absolute value of ADF test statistic is greater than its critical value at alpha 5 percent. By reading the Prob value, Ho is rejected if the Prob figure is less than or equal to alpha 5 percent.

\section{II.4.7.Cointegration Test}

Johansen test on cointegration is based on the following vector error correction model (VECM) of the form (Brooks 2014, 386 and Hamilton 1994, 784)

$$
\Delta y_{t}=\prod y_{t-k}+\Gamma_{1} \Delta y_{t-1}+\Gamma_{2} \Delta y_{t-2}+\ldots \ldots \ldots \ldots+\Gamma_{k-1} \Delta y_{t-(k-1)}+\mu_{t}
$$

As expalined by Brooks $(2014,387)$, the Johansen test centres around an examination of the $\Pi$ matrix The matrix $\Pi$ is interpreted as a long-run coefficient matrix by setting $\Pi y_{t-k}=0$. The test is calculated by finding the rank of $\Pi$ matrix through its eigenvalues that are different from zero.

Table 1. The Formulation of Johansen Cointegration Test

\begin{tabular}{|c|l|l|}
\hline $\begin{array}{c}\text { Null } \\
\text { Hypothesis }\end{array}$ & Eigenvalues & Trace Statistics \\
\hline$r=0$ & $\lambda_{1}$ & $=-T\left[\log \left(1-\lambda_{1}\right)+\log \left(1-\lambda_{2}\right)+\log \left(1-\lambda_{3}\right)+\log \left(1-\lambda_{4}\right)\right]$ \\
\hline$r \leq 1$ & $\lambda_{2}$ & $=-T\left[\log \left(1-\lambda_{2}\right)+\log \left(1-\lambda_{3}\right)+\log \left(1-\lambda_{4}\right)\right]$ \\
\hline$r \leq 2$ & $\lambda_{3}$ & $=-T\left[\log \left(1-\lambda_{3}\right)+\log \left(1-\lambda_{4}\right)\right]$ \\
\hline$r \leq 3$ & $\lambda_{4}$ & $=-T\left[\log \left(1-\lambda_{4}\right)\right]$ \\
\hline
\end{tabular}

The process of testing begins with the testing of $\mathrm{Ho}: \mathrm{r}=0$ (there is no cointegration vectors). If Ho is accepted, the process of testing stops because no evidence for the cointegration presence. If Ho is rejected, the testing process proceeds with the testing of the hypotheses $r \leq 1, r \leq 2$, and so on. If $n$ is the number of variables, the number of cointegrating equation is $\mathrm{h}$ where $\mathrm{h}<\mathrm{n}$. The null hypothesis is that there are $r$ or fewer cointegrating vectors. 
Application software EVIEWS provides critical values at 1\% and 5\% alpha. The null is eccepted if the resulted eigenvalue is lower than its critical value. Or, the null hypothesis is accepted if the trace statistic is lower than its critical value.

\section{II.4.8.The Vector of Error Correction Model (VECM)}

The representation of VECM is as follows.

$$
\begin{aligned}
& \Delta \text { Loan }=\alpha+\sum_{t=1}^{p} \beta_{i}{\Delta \text { Loan }_{t-i}}+\sum_{j=1}^{q} \lambda_{j} \Delta \text { Dep }_{t-j}+\varphi_{1} E C T_{t-1}+\varepsilon_{t} \\
& \Delta \text { Dep }=\delta+\sum_{t=1}^{p} \gamma_{i} \Delta \text { Loan }_{t-i}+\sum_{j=1}^{q} \pi_{j} \Delta \text { Dep }_{t-j}+\varphi_{2} E C T_{t-1}+v_{t}
\end{aligned}
$$

The ECM is a model that distinguishes the Granger causalities in the short and long run. Then the lag of the individual coefficients is an indicator of the short-run relationship. Furthermore, the coefficient of $E C T_{t-1}$ indicates long-run causality. The VECM only provides the existence of cointegration between variables but does not does not describe the causality direction. The Granger causality model and VECM will be used to determine the direction of causality.

\section{II.4.9.Granger Causality Test}

Since the cointegration test between variables is unable to explain the direction of causality, then the Granger causality test provide the direction. In the VAR models, varibles included in the model should be those that depend on one to another. The Granger's Causality test is stated using the following equations.

$$
\begin{aligned}
& Y_{t}=\sum_{t=1}^{n} \alpha_{t} X_{t-i}+\sum_{j=l}^{n} \beta_{j} Y_{t-j}+\mu_{1 t} \\
& X_{t}=\sum_{t=1}^{m} \lambda_{t} X_{t-i}+\sum_{j=l}^{m} \gamma_{j} Y_{t-j}+\mu_{2 t}
\end{aligned}
$$

Based on the results of the two equations above, there will be four possible conclusions as follows; First, unidirectional causality from $\mathrm{X}$ to $\mathrm{Y}$. This happens if $\sum \alpha_{i} \neq 0$ and $\sum \gamma_{j}=0$. Second, unidirectional causality from $\mathrm{Y}$ to $\mathrm{X}$ when $\sum \alpha_{i}=0$ and $\sum \gamma_{j} \neq 0$

Third, bilateral causality, that is, $\mathrm{X}$ affects $\mathrm{Y}$ and $\mathrm{Y}$ affects $\mathrm{X}$ that is if $\sum \alpha_{i} \neq 0$ and $\sum \gamma_{j} \neq 0$ Fourth, independent, that is if $\mathrm{X}$ and $\mathrm{Y}$ do not affect each other, that is when $\sum \alpha_{i}=0$ and $\sum \gamma_{j}=0$. In Granger test, if a variable or an event $\mathrm{X}$ is the cause of variable or edvent $Y$, then the variable or an event X precede the variable or an event Y (Hamilton 1994, 303).

The follwings are previous studies related to interdependence of loans and deposits. Study conducted by Nguyen et al (2018) found that in Vietnamese Banks, the volume of deposits significantly affect the volume of loans, and the volume of loans positively affect volumes of deposit but statistically was not significant. John (2014) confimed the unidirectional influence that deposit volumes affect significantly the volume of loans. Olokoyo (2011) investigated the determinants of the behavior of bank loans in Nigeria. The result of this study was that deposit volumes affect the loan volumes 
significantly. Rabab'ah (2015) examined the factors affecting bank loans in Jordania. This study finds that deposit volumes had a positive influence on loan volumes but the influence is not significant. A study conducted by Ghazali dan Abdurahman (2005) supported the important of loan since it affects the performance of economy. Other findings of this study is the existence of one direction of causality, that is, bank deposits influence the loan volumes. Even tough they did not find a two-way causalitry, they find that for fixed deposit case, bank loan affects the deposit volumes.

The current study differs from previous studies in some aspects. This study uses monthly data from 3 sub-industry of banking in Indonesia namely the government-owned banks, the national private banks, and the joint-venture banks. The last are banks with join-ownership of foreign and national banks. This study takes a sample from 2013 to 2017 using monthly data..

\section{RESEARCH METHODOLOGY}

\section{III.1.Research Framework}

Figure 5 below depicts the research framework for the interdependence of Loan and Deposits of this study.

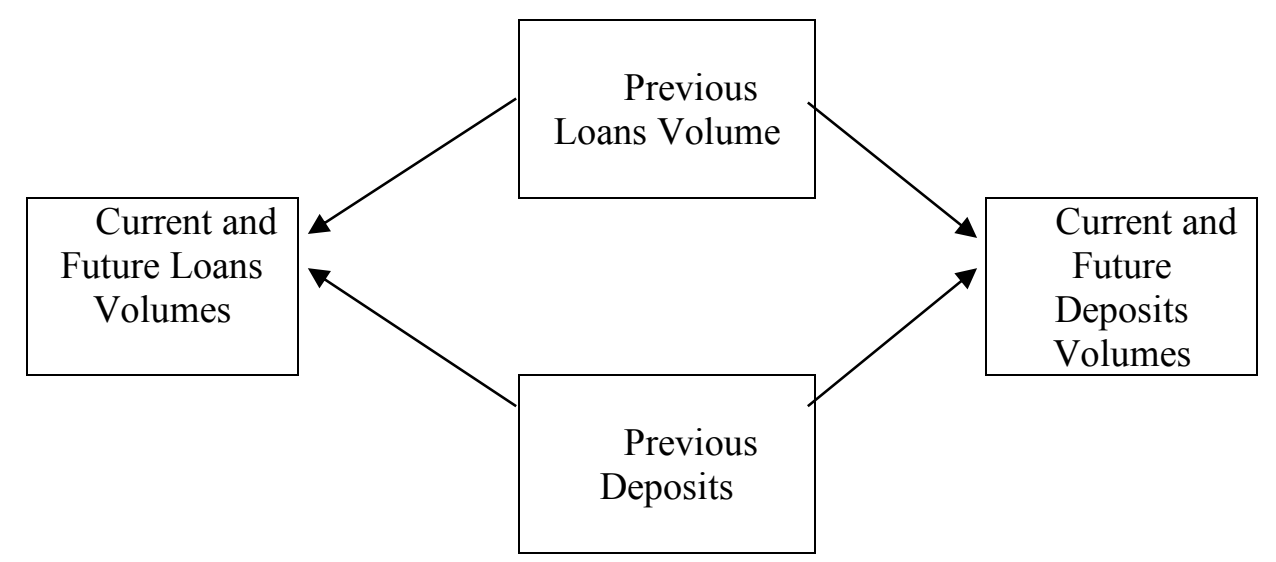

Figure 5. Research in VAR framework

Referring to the Credit Creation Theory of Banking, each bank individually is able to create money in form of demand deposits each time bank granted loans. In this case, the volume of loans affect the volume of deposits Based on the Financial Intermediation Theory of banking, bank collects deposits and then lending them to loan customers, the same as what non-bank financial intermediaries do. In this context, the volume of loans placed by banks will depend on the ability of banks in collecting deposits from society. In VAR framework, previous loans and previous deposits affect current loans, and they also affect current deposits

\section{III.2.Methodology}

The primary objective of this study is to examine the causal relationship between deposits and loans in Indonesian banking sectors. This study will also use Augmented Dickey Fuller test to investigate the stationarity of data. Then, cointegration test is performed to see the existence of long-term relationship of loan and deposits. The interdependence of loans and deposits can be observed by analyzing VAR of VEC models. Finally to see the interdependence of loans and deposits, this study will perform Granger causality tests. 
Proceeding on International Conference of Science Management Art Research Technology (IC-SMART),

Vol. 1 (1), 118-136

Interdependence of Loan and Deposit Volumes at Government-Owned, Private, and Joint-Venture Banks in Indonesia During 2003-2017

Masfar Gazali, Matrodji Mustafa

III.3. Sources of data and period of study

The proyect employs monthly loans and deposits secondary data for the period from January 2003 to December 2017. The data was collected from Indonesian Central Bank publication namely Indonesian Banking Statistics.

\section{III.4.Operational Definition}

For empirical puposes this study defines the loan volume as the combined balance of various types of loans on the book of bank at the end of each month. Deposit volumes are the total combined balance of demand deposits, saving deposits, and time deposits as well as certificate of deposits at the end of each month.

\section{III.5.Analytical Models}

This study uses aggregate time series data for loans and deposits from all government-owned banks combined, private banks, and joint venture banks. Stationary test will be conducted using the ADF test. Johansen cointegration test will be used. The Johansen cointegration test shows the existence of cointegration, it does not describe the direction of causality. Using cointegration model the condition is that loans and deposits must be integrated at the same order. This is the reason that Augmented Dickey Fuller (ADF) unit root test is conducted first. Since the focus of research is examining the interdependence of loans and deposits, the analytical model needed is Vector Autoregression (VAR) or VECM. The VAR model or VECM is used since these models allows loans to depend on deposit and deposits to depend on loans in one model. VAR model or VECM is employed in the context that loan and deposits are two activities provided by on bank as an institution, not provided by two or more different institutions.

Using VAR model and VECM, this study follows the framework depicted in Figure 6

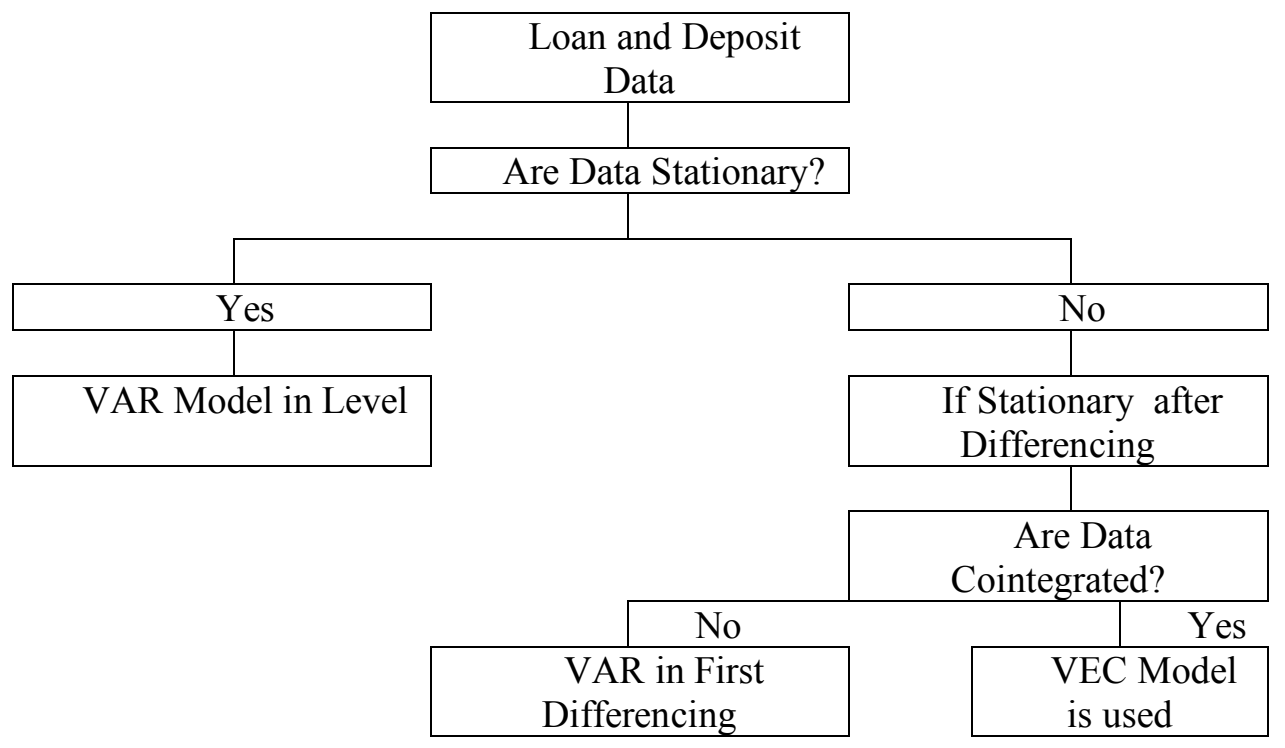

Figure 6. The Process in Developing Model

The framework depicted above explain that if deposit and loan data are both stationary, the VAR model in level will be employed. If deposit and loan data are both stationary after first differenced, then the cointegration test will be applied. If the first differenced data are cointegrated, VECM will be used. If the first differenced data are not cointegrated, VAR model will be used. 


\section{FINDING AND DISCUSSION}

\section{IV.1.The characteristics of Data}

During the study period, the characteristics of loan and deposit volumes at Government-owned Banks, Private Banks, and Joint Venture Banks are presented in Table 2

Tabel 2. Characteristics of Loan and Deposit Volumes Data January 2003 to December 2017

(Billions IDRs)

\begin{tabular}{|l|c|c|c|c|c|c|}
\hline Description & GOVLOAN & GOVDEP & PRIVLOAN & PRIVDEP & JOINLOAN & JOINBDEP \\
\hline Mean & 755870.3 & 932928.6 & 781956.7 & 1000384. & 112863.7 & 97382.69 \\
Median & 589325.0 & 767249.5 & 588468.0 & 800093.5 & 90584.50 & 94790.00 \\
Maximum & 1968419. & 2213902. & 1923254. & 2222149. & 240185.0 & 185388.0 \\
Minimum & 148440.0 & 359504.0 & 122463.0 & 316446.0 & 23424.00 & 19292.00 \\
Std. Dev. & 532676.4 & 532505.6 & 539324.6 & 572203.1 & 74041.86 & 56532.74 \\
Observations & 180 & 180 & 180 & 180 & 180 & 180 \\
\hline
\end{tabular}

Since loan and deposit volumes in each group of banks have an increasing trend from January 2003 to December 2017, then the the minimum figures of loan and deposits volumes are found in Januari 2003. The maximum figures of loan and deposit volumes are found in year 2017. The number of observations from January 2003 to December 2017 is 180 months.

During the study period, for government-owned banks, the means of loan and deposits volumes are IDR 755,870 billions and IDR 932,928 billions respectively. For private banks the means of loan and deposits volumes are IDR 781,957 billions and IDR 1,000,384 billions respectively. For these two groups of banks, the volume of loans is less than the volume of deposits. For joint venture banks, the volume of loans is greater than the volume of deposits.

The range or the difference of maximum and minimum figures of loans in government-owned banks, private banks, and joint venture banks are IDR 1,819,979 billions, IDR 1,800,791 billions and IDR 216,761 billions, respectively. The range of deposit volume in government-owned banks, private banks, and joint venture banks are IDR 1,854,398 billions, IDR 1,905,703 billions and IDR 166,096 billions, respectively.

\section{IV.2.Stasionary Test for Level Data}

The results of Augmented Dickey Fuller (ADF) test of Loans and Deposits for Government-owned Banks (GOVBLOAN), Deposits for Government-owned Banks (GOVBDEP), Loans for Private Banks (PRIVBLOAN), Deposits for Private Banks (PRIVBDEP), Loans for Joint-venture Banks (JOINBLOAN) and Deposits for Joint Venture Banks (JOINBDEP) are presented in the following table.

Summary of Augmented Dickey Fuller (ADF) Test

Table 3. Stationary (ADF) Test of Level Data, Ho: Data has a unit root or not stationary

\begin{tabular}{|c|c|c|c|c|c|c|}
\hline & & & \multicolumn{3}{|c|}{ Critical Values } & \\
\hline Series & $\begin{array}{c}\text { Number } \\
\text { of Lags }\end{array}$ & ADF & Alpha & Alpha & Alpha & Prob \\
& Statics & $1 \%$ & $5 \%$ & $10 \%$ & \\
\hline
\end{tabular}


Proceeding on International Conference of Science Management Art Research Technology (IC-SMART), Vol. 1 (1), 118-136

Interdependence of Loan and Deposit Volumes at Government-Owned, Private, and Joint-Venture Banks in Indonesia During 2003-2017

Masfar Gazali, Matrodji Mustafa

\begin{tabular}{|c|c|c|c|c|c|r|}
\hline GOVLOAN & 12 & - & - & - & - & 0.9814 \\
\hline GOVDEP & 12 & -526607 & 4.013946 & 3.436957 & 3.142642 & \\
\hline PRIVLOAN & 0 & - & - & - & - & 0.9300 \\
& & 0.858888 & 4.010143 & 3.435125 & 3.141565 & \\
\hline PRIVDEP & 2 & - & - & - & - & 0.9633 \\
& & 0.794816 & 4.010740 & 3.435413 & 3.141734 & \\
\hline JOINLOAN & 0 & - & - & - & - & 0.5926 \\
& & 2.008088 & 4.010143 & 3.435125 & 3.141565 & \\
\hline JOINDEP & 0 & - & - & - & - & 0.2877 \\
& & 2.585158 & 4.010143 & 3.435125 & 3.141565 & \\
\hline
\end{tabular}

Table 3 shows that no series is stationary since the Prob figures are all higher than 5\%. Also the absolute figures of ADF statistics are smaller than their respective critical values

\section{IV.3.Stationary Tests for First Differenced Data}

The summary of Augmented Dickey Fuller (ADF) test for first differenced data is presented in Table 4.

Table 4. Stationary Test of First Differenced Data, Ho: Data has a unit root or not stationary

\begin{tabular}{|c|c|c|c|c|c|c|}
\hline \multirow{3}{*}{$\begin{array}{l}\text { Series } \\
\text { D(GOVLOAN) }\end{array}$} & \multirow{3}{*}{$\begin{array}{c}\begin{array}{c}\text { ADF } \\
t- \\
\text { Statistic }\end{array} \\
\\
- \\
4.740314\end{array}$} & \multirow{3}{*}{$\begin{array}{c}\text { Prob } \\
0.0009\end{array}$} & \multicolumn{3}{|c|}{ Critical values } & \multirow{2}{*}{ Conclusion } \\
\hline & & & $1 \%$ & $5 \%$ & $10 \%$ & \\
\hline & & & $\begin{array}{c}- \\
4.014288\end{array}$ & $\begin{array}{c}- \\
3.437122\end{array}$ & $\begin{array}{c}- \\
3.142739\end{array}$ & Stasionary \\
\hline $\mathrm{D}(\mathrm{GOVDEP})$ & 4.740314 & 0.0009 & 4.014288 & 3.437122 & $\begin{array}{c}- \\
3.142739\end{array}$ & Stasionary \\
\hline D(PRIVLOAN) & $\begin{array}{c}- \\
10.48285\end{array}$ & 0.0000 & $\begin{array}{c}- \\
4.010740\end{array}$ & $\begin{array}{c}- \\
3.435413\end{array}$ & $\begin{array}{c}- \\
3.141734\end{array}$ & Stasionary \\
\hline D(PRIVDEP) & $\begin{array}{c}- \\
5.477151\end{array}$ & 0.0000 & $\begin{array}{c}- \\
4.013608\end{array}$ & $\begin{array}{c}- \\
3.436795\end{array}$ & $\begin{array}{c}- \\
3.142546\end{array}$ & Stasionary \\
\hline D(JOINLOAN) & $\begin{array}{c}- \\
14.51120\end{array}$ & 0.0000 & $\begin{array}{c}- \\
4.010440\end{array}$ & $\begin{array}{c}- \\
3.435269\end{array}$ & $\begin{array}{c}- \\
3.141649\end{array}$ & Stasionary \\
\hline D(JOINDEP) & $\begin{array}{c}- \\
15.54859\end{array}$ & 0.0000 & $\begin{array}{c}- \\
4.010440\end{array}$ & $\begin{array}{c}- \\
3.435269\end{array}$ & $\begin{array}{c}- \\
3.141649\end{array}$ & Stasionary \\
\hline
\end{tabular}

Table 4 shows that all series are stationary since the Prob figures are all smaller than 5\% and all the absolute values of ADF statistics are greater than their respective critical values

\section{IV.4.Cointegration Tests}

The following tables report the reults of cointegration tests

Table 5. Cointegration Test of Loans and Deposits at Gov-owned Banks in First Difference 
Proceeding on International Conference of Science Management Art Research Technology (IC-SMART),

Vol. 1 (1), 118-136

Interdependence of Loan and Deposit Volumes at Government-Owned, Private, and Joint-Venture Banks in Indonesia During 2003-2017

Masfar Gazali, Matrodji Mustafa

\begin{tabular}{|c|c|c|c|c|c|c|}
\hline $\begin{array}{c}\text { Hypothesiz } \\
\text { ed } \\
\begin{array}{c}\text { No. of } \\
\text { CE(s) }\end{array}\end{array}$ & $\begin{array}{c}\text { Trace } \\
\text { Statistic }\end{array}$ & $\begin{array}{c}0.05 \\
\text { Critical } \\
\text { Value }\end{array}$ & Prob & $\begin{array}{c}\text { Max- } \\
\text { Eigen } \\
\text { Statistic }\end{array}$ & $\begin{array}{c}0.05 \\
\text { Critical } \\
\text { Value }\end{array}$ & Prob \\
\hline None & 50.223 & 15.494 & 0.000 & 33.268 & 14.264 & 0.000 \\
& 11 & 71 & 0 & 30 & 60 & 0 \\
\hline & 16.954 & 3.8414 & 0.000 & 16.954 & 3.8414 & 0.000 \\
At most 1 & 81 & 66 & 0 & 81 & 66 & 0 \\
\hline
\end{tabular}

Table 5 shows that all trace statistics are greater than their respective critical values at 0.05 level. This result indicates that Loans and Deposits at Government-owned Banks are cointegtaed. The cointegration is also shown by the values Max-Eigen statistics that are greater than their critical values at 0.05 level.

Table 6 Cointegration Test of Loans and Deposits at Private Banks in First Difference

\begin{tabular}{|c|c|c|c|c|c|c|}
\hline & \multicolumn{3}{|c|}{ Trace } & \multicolumn{3}{c|}{ Maximum Eagenvalue } \\
\hline $\begin{array}{c}\text { Hypothesiz } \\
\text { ed } \\
\begin{array}{c}\text { No. of } \\
\text { CE(s) }\end{array}\end{array}$ & $\begin{array}{c}\text { Trace } \\
\text { Statistic }\end{array}$ & $\begin{array}{c}0.05 \\
\text { Critical } \\
\text { Value }\end{array}$ & Prob & $\begin{array}{c}\text { Max- } \\
\text { Eigen } \\
\text { Statistic }\end{array}$ & $\begin{array}{c}0.05 \\
\text { Critical } \\
\text { Value }\end{array}$ & Prob \\
\hline None & 23.567 & 15.494 & 0.002 & 13.821 & 14.264 & 0.058 \\
& 65 & 71 & 5 & 43 & 60 & 6 \\
\hline & 9.7462 & 3.8414 & 0.001 & 9.7462 & 3.8414 & 0.001 \\
At most 1 & 22 & 66 & 8 & 22 & 66 & 8 \\
\hline
\end{tabular}

Table 6 shows that all trace statistics are greater than their respective critical values. This result indicates the existence of cointegration of Loans and Deposits at Private Banks. The existence of cointegration is also shown by Max-Eigen statistics that are greater than their critical values. This conclusion is also supported by the Prob figure of less than 0.05 or 0.10

Table 7 Cointegration Test of Loans and Deposits at Joint-Venture Banks in First Difference

\begin{tabular}{|c|c|c|c|c|c|c|}
\hline & \multicolumn{3}{|c|}{ Trace } & \multicolumn{3}{c|}{ Maximum Eagenvalue } \\
\hline $\begin{array}{c}\text { Hypothesiz } \\
\text { ed } \\
\begin{array}{c}\text { No. of } \\
\text { CE(s) }\end{array}\end{array}$ & $\begin{array}{c}\text { Trace } \\
\text { Statistic }\end{array}$ & $\begin{array}{c}0.05 \\
\text { Critical } \\
\text { Value }\end{array}$ & Prob & $\begin{array}{c}\text { Max- } \\
\text { Eigen } \\
\text { Statistic }\end{array}$ & $\begin{array}{c}0.05 \\
\text { Critical } \\
\text { Value }\end{array}$ & Prob \\
\hline None & 8.3772 & 15.494 & 0.426 & 8.0932 & 14.264 & 0.369 \\
& 82 & 71 & 0 & 11 & 60 & 3 \\
\hline & 0.2840 & 3.8414 & 0.594 & 0.2840 & 3.8414 & 0.594 \\
At most 1 & 71 & 66 & 0 & 71 & 66 & 0 \\
\hline
\end{tabular}

Table 7 shows that all trace statistics are smaller than their respective critical values. This result indicates the existence of no-cointegration of Loans and Deposits at joint venture banks. The existence of no-cointegration is also present by Max-Eigen statistics that are smaller than their critical values. This conclusion is suported by the Prob figures that are greater than 0.05 or 5 percent. 
Proceeding on International Conference of Science Management Art Research Technology (IC-SMART), Vol. 1 (1), 118-136

Interdependence of Loan and Deposit Volumes at Government-Owned, Private, and Joint-Venture Banks in Indonesia During 2003-2017

Masfar Gazali, Matrodji Mustafa

\section{IV.5.VEC Estimates for Government dan Private Banks}

The vector error correction for Government-Owned Banks and Private Banks are presented in Table 8 below

Table 8. VEC Estimates for Government-owned and Private Banks

\begin{tabular}{|c|c|c|c|c|c|}
\hline \multicolumn{3}{|c|}{ GOVERNMENT BANKS } & \multicolumn{3}{|c|}{ PRIVATE BANKS } \\
\hline & D(GOVLOA & & Error Correction & (PRIVLOAI & \\
\hline Error Correction: & N) & $\mathrm{D}(\mathrm{GOVDEP})$ & CointEq1 & ) & D(PRIVDEP) \\
\hline CointEq1 & 0.05355 & 0.08039 & t-value & 0.02494 & 0.02388 \\
\hline t-value & {$[5.8764]$} & {$[3.84671]$} & & [ 4.4883] & {$[3.8570]$} \\
\hline D(GOVLOAN(- & & & D(PRIVLOAN(- & & \\
\hline 1)) & 0.20576 & 0.41772 & 1)) & 0.10331 & 0.22476 \\
\hline t-value & {$[1.8445]$} & {$[1.63267]$} & t-value & [0.9399] & [ 1.8349$]$ \\
\hline D(GOVLOAN(- & & & D(PRIVLOAN(- & & \\
\hline 2)) & -0.23027 & 0.40617 & 2)) & -0.02768 & 0.13431 \\
\hline t-value & {$[-2.0845]$} & {$[1.6031]$} & t-value & {$[-0.2505]$} & [ 1.0910$]$ \\
\hline D(GOVLOAN(- & & & D(PRIVLOAN(- & & \\
\hline 3)) & 0.40620 & 0.80451 & 3)) & 0.21653 & 0.03155 \\
\hline t-value & {$[3.8707]$} & [ 3.3426] & t-value & [ 1.9557$]$ & {$[0.2557]$} \\
\hline D(GOVLOAN(- & & & & & \\
\hline 4)) & -0.28192 & 0.45435 & D(PRIVDEP(-1)) & -0.09692 & -0.02581 \\
\hline t-value & {$[-2.5317]$} & [1.7789] & t-value & {$[-0.9778]$} & {$[-0.2337]$} \\
\hline D(GOVDEP(-1)) & 0.21968 & 0.40784 & D(PRIVDEP(-2)) & -0.14635 & -0.27867 \\
\hline t-value & {$[4.7635]$} & {$[3.8557]$} & t-value & {$[-1.49674]$} & {$[-2.5573]$} \\
\hline $\mathrm{D}(\operatorname{GOVDEP}(-2))$ & 0.11389 & 0.24499 & D(PRIVDEP(-3)) & 0.31514 & -0.14809 \\
\hline $\mathrm{t}$-value & [2.2392] & [2.1001] & t-value & [3.2344] & {$[-1.36378]$} \\
\hline $\mathrm{D}(\mathrm{GOVDEP}(-3))$ & 0.10858 & 0.27912 & $\mathrm{C}$ & 13224.69 & 11792.08 \\
\hline t-value & [2.1226] & {$[2.3790]$} & t-value & [ 7.3593] & [ 5.88825] \\
\hline $\mathrm{D}(\operatorname{GOVDEP}(-4))$ & 0.01542 & -0.11274 & & & \\
\hline t-value & [ 0.2984$]$ & {$[-0.9511]$} & & & \\
\hline $\mathrm{C}$ & 13422.41 & 16901.28 & & & \\
\hline t-value & [ 6.8028] & [3.7348] & & & \\
\hline F-statistic & 16.78601 & 10.10388 & F-statistic & 4.715505 & 5.269533 \\
\hline
\end{tabular}

Table 8 shows that the cointegration coefficients for both Government-owned and Private Banks are significant with their t-values are significant. At government-owned banks, loans are influenced by deposits with $t$-values are greater than 2 and, deposits are also influenced by loans with $t$-value at lag 3 is greater than 2. This is the same as the result of Granger test presented in Table 7 in which loans depend on deposits and deposits depend on loans.

Table 8 also shows that at privaye banks, loans are affected by deposits specifically at lag 3 in which $\mathrm{t}$ value is greater than 2. In private banks, the relationship between loan and deposit is in one direction that is loans are affected by deposits and not in the other way around. This result is the same as the result of Granger causality test shown in Table 7.

\section{IV.6.Granger Causality test for Government and Private Banks}


Since the Johansen cointegration test shows the existence of cointegration, it does not describe the direction of causality. For this purpose Granger causality test is used to determine the direction of causality of loans and deposits.

Table 9. VEC Granger Causality/Block Exogeneity Wald Tests

\begin{tabular}{|c|c|c|c|c|c|c|c|}
\hline \multicolumn{4}{|c|}{ Government Banks } & \multicolumn{4}{|c|}{ Private Banks } \\
\hline \multicolumn{4}{|c|}{ Dependent variable: D(GOVLOAN) } & \multicolumn{4}{|c|}{ Dependent variable: D(PRIVLOAN) } \\
\hline Excluded & Chi-sq & df & Prob. & Excluded & $\begin{array}{l}\text { Chi-sq } \\
13.2166\end{array}$ & $\mathrm{df}$ & Prob. \\
\hline $\mathrm{D}(\mathrm{GOVDEP})$ & 29.8558 & 4 & 0.0000 & D(PRIVDEP) & $\begin{array}{c}2 \\
13.2166\end{array}$ & 3 & 0.0042 \\
\hline All & 29.8558 & 4 & 0.0000 & All & 2 & 3 & 0.0042 \\
\hline \multicolumn{4}{|c|}{ Dependent variable: $\mathrm{D}(\mathrm{GOVDEP})$} & \multicolumn{4}{|c|}{ Dependent variable: D(PRIVDEP) } \\
\hline Excluded & Chi-sq & df & Prob. & Excluded & Chi-sq & $\mathrm{df}$ & Prob. \\
\hline $\mathrm{D}(\mathrm{GOVLOAN})$ & 16.5 & 4 & 0.0023 & D(PRIVLOAN) & 4.3 & 3 & 0.2283 \\
\hline All & 16.5826 & 4 & 0.0023 & All & 4.32643 & 3 & 0.2283 \\
\hline
\end{tabular}

Based on the Granger Causality test reported in Table 9, at government banks, loans depend on deposits and deposits depend on loans. For private banks, loan depends on deposit but deposit does not depend on loan.

\section{IV.7.The VAR Estimates for Joint-venture Banks}

The vector autoregression (VAR) for joint venture banks is presented in Table 10 below

Table 10. VAR Estimate for Joint Venture Banks

\begin{tabular}{|ccc|}
\hline \multicolumn{3}{|c|}{ Vector Autoregression Estimates } \\
& D(JOINLOA & \\
N) & D(JOINDEP) \\
D(JOINLOAN(- & & \\
1)) & -0.007454 & 0.081742 \\
t-value & {$[-0.07590]$} & {$[0.84359]$} \\
D(JOINLOAN(- & & \\
2) $)$ & 0.223509 & 0.190432 \\
t-value & {$[2.23714]$} & {$[1.93175]$} \\
D(JOINLOAN(- & & \\
3)) & 0.162256 & 0.134274 \\
t-value & {$[1.60714]$} & {$[1.34790]$} \\
D(JOINDEP(-1)) & -0.034707 & -0.191016 \\
t-value & {$[-0.34771]$} & {$[-1.93944]$} \\
D(JOINDEP(-2)) & -0.218044 & -0.173139 \\
t-value & {$[-2.11372]$} & {$[-1.70103]$} \\
D(JOINDEP(-3)) & -0.059102 & -0.055377 \\
t-value & {$[-0.57232]$} & {$[-0.54347]$} \\
\hline
\end{tabular}


Proceeding on International Conference of Science Management Art Research Technology (IC-SMART),

Vol. 1 (1), 118-136

Interdependence of Loan and Deposit Volumes at Government-Owned, Private, and Joint-Venture Banks in Indonesia During 2003-2017

Masfar Gazali, Matrodji Mustafa

F-statistic $\quad-0.861073 \quad 0.197513$

Table 10 shows the F-statistics are very low indicating that all variables together in the model do not affect dependent variable significantly. This is supported by the result of Granger test presented in Table 11 in which loans do not depend on deposits and deposits do not depend on loans

Table 11. Granger Test for Joint Venture Bank

\begin{tabular}{|cccc|}
\hline \multicolumn{4}{|c|}{ VAR Granger Causality/Block Exogeneity Wald Tests } \\
\multicolumn{4}{|c|}{ Dependent variable: D(JOINBLOAN) } \\
Excluded & Chi-sq & df & Prob. \\
D(JOINBDEP) & 4.527574 & 3 & 0.2098 \\
All & 4.527574 & 3 & 0.2098 \\
& Dependent variable: D(JOINBDEP) & \\
Excluded & Chi-sq & df & Prob. \\
D(JOINBLOAN) & 5.965175 & 3 & 0.1133 \\
All & 5.965175 & 3 & 0.1133 \\
\hline
\end{tabular}

\section{Discussion}

The findings of this study show different results among three-group of banks. At government-owned banks, loans and deposits affect each other. At private banks, deposits affect loans but not the other way around. At joint-venture banks the result is that deposits have no impact on loans and loans also have no impact on deposits.

It can be stated that at government awned banks, the customer relationship management works well in addition following the intermediatory functions. The effectiveness of customer relationship strategy can be shown by the existence of interdependence of loans and deposits.

Since in intense competition both in loan and deposits markets, a modern bank should have a good customer relationship. As discussed previously, this leads to the direction of causality that loan affects deposits. As a bank still maintains its function as a financial intermediary, the causality is that deposits affect loans. For this reason, it can be argued that a successful bank in competition will have its loan depends on deposits and its deposits depend on loan. Private banks follow the traditional intermediatory theory. Joint venture banks follows no theory.

\section{CONCLUSION AND FURTHER RESEARCH}

This study examines the interdependence of loans and deposits at government owned banks, private banks, and joint-venture banks in Indonesia. Based on Augmented Dickey Fuller tests, this study finds that all the series are stationary after first-differencing. The loan and deposit volumes are cointegrated at government owned banks and private banks but not at joint-venture banks. Analyzing the interdependence of loans and deposits, this study uses vector error correction model (VECM) for government owned and private banks. The vector autoregressive (VAR) model is used for jointventure banks. Based on Granger Causality tests, the interdependence of loans and deposits exists only in government-owned banks. In private banks, the causality present only in one direction, that is the loans depend on deposits. No causality of loans and deposits was found in joint venture banks.

\section{REFERENCES}




\section{Available online at: http://proceeding.rsfpress.com/index.php/ic-smart/index \\ Proceeding on International Conference of Science Management Art Research Technology (IC-SMART) \\ Volume 1 Number 1 (2020): 118-136}

Abel, S; Khobai, H and LeRoux, P (2017); Evaluating Competition in the Loan and Deposit Market using the Boone Indicator Approach; Southern African Business Review, Volume 21, 2017 pp 274-291

Ahtiala, Pekka; (2005), The new theory of commercial banking and bank lending behavior; Scottish Journal of Political Economy, Vol. 52, No. 5.

Aluko, Olufemi A, and Ajayi, Michael Adebayo; (2018), Determinants of banking sector development: Evidence from Sub-Saharan African countries; Borsa Istanbul Review, 18-2 pp. 122-139

Brooks, Chris; (2014), Introductory Econometrics for Finance, 3rd edition, Cambridge University Press.

Franses, Philip Hans; (2000), Time Series Models for Business and Economic Forecasting, Cambridge University Press.

Financial Sector Development Indicators (FSDI), Financial Sector Operations and Policy, FSDI@worldbank.org

Gelbard, E., and P. Leite, (1999), "Measuring Financial Development in Sub-Saharan Africa," IMF Working Paper 99/105 (Washington: International Monetary Fund).

Ghazali, Noor Azlan and Abdurrahman, Aisyah; (2005), The Transmission Mechanisme of Monetary Policy in Malaysia Through Bank Loans or Deposits?, IIUM Journal of Economics and Management 13, no.1.

Hamilton, James D; (1994), Time Series Analysis, Princeton University Press, 1994

Jayaratne, J. and Strahan, P., (1996), The finance-growth nexus: evidence from bank branch deregulation, Quarterly Journal of Economics, Vol. 3 No. 3, pp. 639-670.

John, Akinyomi, O; (2014), Effect of Deposit Volume on Banks' Lending Behaviour in the Nigerian Post-Consolidation Era; International Journal of Innovation and Scientific Research; Vol. 4 No. 1 Jul., pp. 21-25

Kashyap, Anil K; Rajan, Raghuram dan Stein, Jeremy C; (2002), Banks as Liquidity Providers: An Explanation for the Coexistence of Lending and Deposit-Taking; The Journal of Finance, Volume LVII, No. 1.

Kapsis, L, (2012), Competition law and policy for the eu banking sector in a period of increased economic uncertainty, International Journal of Law and Management, Vol. 54 No. 4, pp. 284-301.

Koch, Timothy W. and MacDonald, S. Scott; (2015), Bank Management, CENGAGE Larning.

Levine, R. (2005). Finance and growth: Theory and evidence. Handbook of Economic Growth, 1, 865-934

Lewis, Mervyn K; (1992), Modern Banking in Theory and Practices; Revue Economique, Volume 43, No 2.

Mettenheim, Kurt; (2013), Back to Basics in Banking Theory and Varieties of Finance Capitalism, AEL: A Convivium; 3(3): 357-405.

Nguyen, Tram; Tripe, David; and Ngo, Thanh; (2018), Operational Efficiency of Bank Loans and Deposits: A Case Study of Vietnamese Banking System, International Journal of Financial Studies, 6, p.14.

Olokoyo, Felicia Omowunmi; (2011), Determinants of Commercial Banks' Lending Behavior in Nigeria; International Journal of Financial Research, Vol. 2, No. 2; July.

Rabab'ah, Mwafaq, (2015), Factors Affecting the Bank Credit: An Empirical Study on the Jordanian Commercial Banks, International Journal of Economics and Finance; Vol. 7, No. 5.

Rose, Peter S and Hudgins, Sylvia C. (2013), Bank Management and Financial Services, McGrawHill.

Saunders, Anthony and Cornett, Marcia Millon; (2004), Financial Markets and Institutions, McGraw Hill.

Tsay, Ruey S; (2010), Analysis of Financial Time Series, John Wiley \& Son.

Werner, Richard A; (2016), A lost century in economics: Three theories of banking and the conclusive evidence, International Review of Financial Analysis 46, pp 361-379. 
Proceeding on International Conference of Science Management Art Research Technology (IC-SMART), Vol. 1 (1), 118-136

Interdependence of Loan and Deposit Volumes at Government-Owned, Private, and Joint-Venture Banks in Indonesia During 2003-2017

Masfar Gazali, Matrodji Mustafa 